\title{
Design of $\mathrm{Sr}_{0.7} \mathrm{R}_{0.3} \mathrm{CoO}_{3-\delta}(\mathrm{R}=\mathrm{Tb}$ and $\mathrm{Er})$ Perovskites Performing as Cathode Materials in Solid Oxide Fuel Cells
}

\author{
V. Cascos, ${ }^{a, *, z}$ A. Aguadero, ${ }^{b, *}$ G. Harrington, ${ }^{b}$ M. T. Fernández-Díaz, ${ }^{c}$ and J. A. Alonso ${ }^{a}$ \\ ${ }^{a}$ Instituto de Ciencia de Materiales de Madrid, C.S.I.C., Cantoblanco E-28049, Spain \\ ${ }^{b}$ Department of Materials, Imperial College London SW7 2AZ, United Kingdom \\ ${ }^{c}$ Institut Laue Langevin, Grenoble, F-38042, France
}

$\mathrm{Sr}_{0.7} \mathrm{R}_{0.3} \mathrm{CoO}_{3-\delta}(\mathrm{R}=\mathrm{Tb}$ and $\mathrm{Er})$ tetragonal perovskites have been prepared and evaluated as mixed ionic-electronic cathodes for SOFC. Neutron powder diffraction (NPD) measurements evidenced that both compounds are oxygen hypo-stoichiometric with long-range order of oxygen vacancies that leads to a tetragonal perovskite-type superstructure (s.g. I $4 / \mathrm{mmm}$ ) stable within the whole temperature range under study. The oxygen vacancies located mainly in the equatorial oxygen positions exhibit large displacement factors. The high oxygen mobility in $\mathrm{Sr}_{0.7} \mathrm{~Tb}_{0.3} \mathrm{CoO}_{3-\delta}$ was confirmed by ${ }^{18} \mathrm{O}$ oxygen labeling followed by Secondary Ion Mass Spectrometry (SIMS) with values of oxygen self-diffusion of $1.29 \times 10^{-10} \mathrm{~cm}^{2} / \mathrm{s}$ at $525^{\circ} \mathrm{C}$. Polarization resistances with LSGM as electrolyte gave values as low as $0.011 \Omega \cdot \mathrm{cm}^{2}$ and maximum output powers of $570 \mathrm{~mW} / \mathrm{cm}^{2}$ at $850^{\circ} \mathrm{C}$ were obtained in test cells set in electrolyte-supported configuration. Electrical conductivity, thermal and chemical expansion and stability measurements confirm the potential of these materials as cathodes for SOFC.

(c) The Author(s) 2017. Published by ECS. This is an open access article distributed under the terms of the Creative Commons Attribution Non-Commercial No Derivatives 4.0 License (CC BY-NC-ND, http://creativecommons.org/licenses/by-nc-nd/4.0/), which permits non-commercial reuse, distribution, and reproduction in any medium, provided the original work is not changed in any way and is properly cited. For permission for commercial reuse, please email: oa @electrochem.org. [DOI: 10.1149/2.0031710jes] All rights reserved.

(cc) BY-NC-ND

Manuscript submitted January 31, 2017; revised manuscript received April 21, 2017. Published June 3, 2017. This paper is part of the JES Focus Issue on Oxygen Reduction and Evolution Reactions for High Temperature Energy Conversion and Storage.

Nowadays it is frequent to hear about the so-called "hydrogen economy", which is based on replacing fossil fuels with this gas. The combustion of hydrogen is clean and releases more energy than any other fuel per unit weight. The utilization of hydrogen as an energy vector relies on the replacement of the current couple constituted by "hydrocarbon fuel-combustion engine" by the "hydrogen-fuel cell" binomial. Among the fuel cells, solid oxide fuel cells (SOFC) are intended to be used for stationary applications and exhibit a superior performance compared to other fuel-cell types. ${ }^{1-3}$ For practical reasons it would be ideal the reduction of the SOFC operating temperature to lower temperatures $\left(650-850^{\circ} \mathrm{C}\right)$ without detriment of the cell efficiency. Therefore, it is essential to innovate in electrode materials in order to enhance their catalytic properties and their mixed ionic-electronic conductivity, achieving much faster kinetics for the two half-reactions. ${ }^{4}$ In this work we have designed, prepared and characterized new mixed ionic-electronic conductors (MIECs) based on the family of perosvkites $\operatorname{Sr}_{0.7} \mathrm{R}_{0.3} \mathrm{CoO}_{3-\delta}(\mathrm{R}=\mathrm{Tb}$ and $\mathrm{Er})$ as cathode materials for SOFC.

Cobalt-based perovskite compounds have attracted huge attention as IT-SOFC (intermediate-temperature SOFC) cathodes due to their mixed-conducting characteristics and high ion-conductivity in the intermediate temperature range. ${ }^{5-7}$ Due to their properties, hightemperature $\mathrm{SrCoO}_{3-\delta}$ phases with cubic 3C-like crystal structures (where the $\mathrm{CoO}_{\mathrm{x}}$ coordination polyhedra share corners) are presented as mixed conductors with very high oxygen permeability. ${ }^{8,9}$ Unfortunately, this cubic polymorph is not stable below $900^{\circ} \mathrm{C}$ where a $3 \mathrm{C}$-cubic to $2 \mathrm{H}$-hexagonal phase transition takes place when the material undergoes a slow cooling process. In the $2 \mathrm{H}$-hexagonal phase, characterized by a tolerance factor higher than 1 , the crystal structure contains columns of $\mathrm{CoO}_{6}$ octahedra sharing faces, which is detrimental for its electronic transport properties.

The stabilization of $\mathrm{SrCoO}_{3-\delta}$ in a tetragonal perovskite phase has been achieved in previous works by different doping strategies. ${ }^{10-16}$ In particular, $\mathrm{Sr}_{0.7} \mathrm{Y}_{0.3} \mathrm{CoO}_{3-\delta}$ and $\mathrm{Sr}_{0.7} \mathrm{Ho}_{0.3} \mathrm{CoO}_{3-\delta}$ compounds were described as excellent cathode materials for SOFCs using a solid oxide electrolyte LSGM and hydrogen as fuel. ${ }^{14,15}$ In these materials the stabilization of a $3 \mathrm{C}$-type structure is induced by a decrease of the

\footnotetext{
*Electrochemical Society Member.
}

${ }^{\mathrm{z} E}$-mail: vcascos@icmm.csic.es tolerance factor. This is caused by the size and charge effects resulting from the introduction of $\mathrm{R}^{3+}$ ions at the $\mathrm{Sr}^{2+}$ perovskite positions, leading to the wanted octahedral corner-sharing configuration.

The aim of this work was to stabilize two new perovskites with $\mathrm{Sr}_{0.7} \mathrm{Er}_{0.3} \mathrm{CoO}_{3-\delta}$ and $\mathrm{Sr}_{0.7} \mathrm{~Tb}_{0.3} \mathrm{CoO}_{3-\delta}$ compositions and evaluate their performance as mixed ionic-electronic cathode material in SOFCs. In this regard, a detailed study of the structural, thermal and transport properties of these oxides has been performed and correlated to their electrochemical performance as cathodes in LSGM-based SOFCs.

\section{Experimental}

$\mathrm{Sr}_{0.7} \mathrm{R}_{0.3} \mathrm{CoO}_{3-\delta}(\mathrm{R}=\mathrm{Tb}$ and $\mathrm{Er})$ polycrystalline powders were prepared by a soft- chemistry citrate-nitrate route. Stoichiometric amounts of analytical grade $\mathrm{Tb}_{4} \mathrm{O}_{7}$ or $\mathrm{Er}_{2} \mathrm{O}_{3}, \mathrm{Sr}\left(\mathrm{NO}_{3}\right)_{2}$ and $\mathrm{Co}\left(\mathrm{NO}_{3}\right)_{2} \cdot 6 \mathrm{H}_{2} \mathrm{O}$ were dissolved under stirring in a citric-acid aqueous solution containing some drops of $\mathrm{HNO}_{3}$. The solutions were slowly evaporated, leading to an organic resin that contains a homogeneous distribution of the involved cations. The formed resins were dried at $120^{\circ} \mathrm{C}$ and decomposed at $600^{\circ} \mathrm{C}$ for $12 \mathrm{~h}$ in order to eliminate the organic materials and the nitrates. The obtained precursors were then heated at $1100^{\circ} \mathrm{C}$ for $12 \mathrm{~h}$ in air. After the thermal treatment, the samples were quenched by opening the furnace door at $1100^{\circ} \mathrm{C}$ and removing the samples to ambient conditions, thus leading to the stabilization of the tetragonal perovskite-oxide phases. For the structural refinement, NPD patterns were collected at the D2B diffractometer of the Institut Laue-Langevin, Grenoble, with a wavelength $\lambda=1.594 \AA$ within the $2 \theta$ range from 10 to $155^{\circ}$ at $25^{\circ} \mathrm{C}$ for $\mathrm{Sr}_{0.7} \mathrm{Er}_{0.3} \mathrm{CoO}_{3-\delta}$ and at $25,200,400,600$ and $800^{\circ} \mathrm{C}$ for $\mathrm{Sr}_{0.7} \mathrm{~Tb}_{0.3} \mathrm{CoO}_{3-\delta}$. For the $25^{\circ} \mathrm{C}$ measurements, about $2 \mathrm{~g}$ of sample was contained in a vanadium can. For the $\mathrm{T} \geq 200^{\circ} \mathrm{C}$ collection, the sample was contained in a quartz tube open to the atmosphere and placed in the isothermal zone of a furnace with a vanadium resistor operating under vacuum $\left(\mathrm{P}_{\mathrm{O} 2} \approx 1 \times 10^{-6}\right.$ Torr); in all cases a time of $3 \mathrm{~h}$ was required to collect a full diffraction pattern. The NPD data were analyzed by the Rietveld method ${ }^{17}$ with the FULLPROF program. ${ }^{18}$ A pseudo-Voigt function was chosen to generate the line shape of the diffraction peaks. The irregular background coming from the quartz container was extrapolated from points devoid of reflections. In the final run, the following parameters were refined: scale factor, background points, zero shift, half-width, 
pseudo-Voigt corrected for asymmetry parameters, unit-cell parameters, positional coordinates and isotropic displacement factors for all the atoms and anisotropic factors for O4 oxygen atoms. The coherent scattering lengths of $\mathrm{Sr}, \mathrm{Tb}, \mathrm{Er}, \mathrm{Co}$ and $\mathrm{O}$ were 7.02, 7.38, 7.79, 2.49 and $5.805 \mathrm{fm}$, respectively.

Measurements of the thermal expansion coefficient required the use of sintered cylindrical samples ( $5 \mathrm{~mm}$ diameter $\times 2 \mathrm{~mm}$ thickness) and measurements of the conductivity required the use of sintered bars samples $\left(3 \times 3 \times 10 \mathrm{~mm}^{3}\right)$. Densification was performed by uniaxial pressing of pellets that were subsequently sintered at $1100^{\circ} \mathrm{C}$ for 12 $\mathrm{h}$; the obtained density is around 95-98\%. Thermal expansion of the sintered samples was carried out in a dilatometer Linseis L75HX1000, between 25 and $900^{\circ} \mathrm{C}$ in air. The conductivity was measured between 25 and $850^{\circ} \mathrm{C}$ in air by the four-point method in bar-shaped pellets under DC currents between 0.1 and $0.5 \mathrm{~A}$. The currents were applied and collected with a Potentiostat-Galvanostat AUTOLAB PGSTAT 302 from ECO CHEMIE.

Oxygen tracer diffusion profiling was employed to measure the self-diffusion coefficient $\left(D^{*}\right)$ and surface exchange coefficient $(k)$ of $\mathrm{Sr}_{0.7} \mathrm{~Tb}_{0.3} \mathrm{CoO}_{3-\delta} . k$ is also a measure of the oxygen reduction reaction to give $\mathrm{O}^{2-}$ ions that diffuse across the electrolyte. The isotopic exchange was performed on a dense polished sample. In order to achieve a high density, firstly the powder was milled in a ball mill with zirconia balls in ethanol for 3 hours. Next, approximately 0.70 $\mathrm{g}$ of the powder was isostatically pressed at $300 \mathrm{MPa}$ into $11 \mathrm{~mm}$ diameter pellets and subsequently sintered at $1200^{\circ} \mathrm{C}$ for $5 \mathrm{~h}$ in air. A density of $98 \%$ of the crystallographic value was obtained under these conditions. The pellet was then polished down to a $0.25 \mu \mathrm{m}$ finish using successive grades of diamond suspension. Finally, the polished pellet was cleaned with ethanol in an ultrasonic cleaner for 5 minutes. Before the ${ }^{18} \mathrm{O}$ exchange anneals, the $\mathrm{Sr}_{0.7} \mathrm{~Tb}_{0.3} \mathrm{CoO}_{3-\delta}$ pellet was pre-annealed in oxygen of a natural isotope abundance at 200 mbar for 3 hours at $525^{\circ} \mathrm{C}$ and quenched to room temperature with liquid $\mathrm{N}_{2}$. This step was necessary to ensure that the pellet was in equilibrium at the exchange temperature and oxygen partial pressure. Next, the ${ }^{18} \mathrm{O}$ exchange was performed for 30 minutes at $525^{\circ} \mathrm{C}$ in enriched ${ }^{18} \mathrm{O}$ gas at $200 \mathrm{mbar}$. The sample was rapidly heated to the annealing temperature and quenched to room temperature after the exchange with liquid $\mathrm{N}_{2}$.

The oxygen tracer diffusion profile was analyzed using a timeof-flight secondary ion mass spectrometry (ToF-SIMS) instrument (ION-TOF GmbH, Germany) and the line scanning technique. ${ }^{19,20}$ In this technique, the ${ }^{18} \mathrm{O}$ annealed sample was cut perpendicular to the exchanged surface, polished and analyzed by ToF-SIMS along the cut surface. The ${ }^{18} \mathrm{O}$ distribution was mapped on the sectioned sample in the 'burst alignment' mode using a pulsed $25 \mathrm{keV} \mathrm{Bi}^{+}$analysis beam and $2 \mathrm{keV} \mathrm{Cs}^{+}$sputter gun to clean the surface in-situ. The measured diffusion profile was fitted using a solution to the diffusion equation for a semi-infinite medium given by: ${ }^{21}$

$$
\begin{aligned}
\frac{C(x, t)-C_{b g}}{C_{g}-C_{b g}}= & \operatorname{erfc}\left[\frac{x}{2 \sqrt{D^{*} t}}\right]-\left[\exp \left(\frac{k x}{D^{*}}+\frac{k^{2} t}{D^{*}}\right)\right. \\
& \left.\times \operatorname{erfc}\left(\frac{x}{2 \sqrt{D^{*} t}}+k \sqrt{\frac{t}{D^{*}}}\right)\right]
\end{aligned}
$$

where $C(x, t)$ is the ratio of intensity of ${ }^{18} \mathrm{O}$ signal to the total intensity of $\left({ }^{18} \mathrm{O}+{ }^{16} \mathrm{O}\right)$ in the material as measured by SIMS, $x$ is the distance from the exchanged surface of the specimen and $t$ is the time of the isotope exchange, $C_{b g}$ is the natural isotopic background of ${ }^{18} \mathrm{O}(=0.002), C_{g}$ is the isotope fraction of ${ }^{18} \mathrm{O}$ in the gas during the ${ }^{18} \mathrm{O}$ exchange, $D^{*}$ is the bulk oxygen tracer diffusion coefficient, and $k$ is the surface exchange coefficient. Values of $D^{*}$ and $k$ were obtained by fitting Eq. 1 to the experimental data using a non-linear least square regression script in the MATLAB software (MATLAB, MathWorks).

Ac impedance spectroscopy measurements were carried out in air conditions on symmetrical cells with $\mathrm{La}_{0.8} \mathrm{Sr}_{0.2} \mathrm{Ga}_{0.83} \mathrm{Mg}_{0.17} \mathrm{O}_{3-\delta}$ (LSGM) as electrolyte, in configurations $\mathrm{Sr}_{0.7} \mathrm{~Tb}_{0.3} \mathrm{CoO}_{3-\delta} / \mathrm{LSGM} /$
$\mathrm{Sr}_{0.7} \mathrm{~Tb}_{0.3} \mathrm{CoO}_{3-\delta}$ and $\mathrm{Sr}_{0.7} \mathrm{Er}_{0.3} \mathrm{CoO}_{3-\delta} / \mathrm{LSGM} / \mathrm{Sr}_{0.7} \mathrm{Er}_{0.3} \mathrm{CoO}_{3-\delta}$. For this purpose, inks of the cathode materials were prepared and symmetrically painted onto both surfaces of the sintered LSGM disks obtaining symmetrical electrodes. The cells were calcined at $1000^{\circ} \mathrm{C}$ for $4 \mathrm{~h}$ to obtain a good adherence between the cathodes and the electrolyte. Subsequently, two Pt electrodes were painted onto the cathode surfaces and calcined at $950^{\circ} \mathrm{C}$ for $1 \mathrm{~h}$ to ensure equipotential conditions. The symmetrical cells were placed into a ceramic support and two Pt gauzes were used to collect the current and record the voltage drop through the system. Impedance measurements were performed at 800 and $850^{\circ} \mathrm{C}$ in air, using an AUTOLAB FRA system (PGSTAT30 and FRA2 module) from Eco Chemie B.V. The measurements were carried out in potentiostatic mode from $100 \mathrm{~Hz}$ to $0.1 \mathrm{~Hz}$ in open circuit conditions with a signal amplitude of $50 \mathrm{mV}$.

Single-cell test was conducted by an electrolyte-supported technique with $300-\mu \mathrm{m}$-thick LSGM as the electrolyte. $\mathrm{SrMo}_{0.8} \mathrm{Fe}_{0.2} \mathrm{O}_{3-\delta}$ (SMFO) was used as the anode material, recently developed in our group, ${ }^{22} \mathrm{Sr}_{0.7} \mathrm{~Tb}_{0.3} \mathrm{CoO}_{3-\delta}$ and $\mathrm{Sr}_{0.7} \mathrm{Er}_{0.3} \mathrm{CoO}_{3-\delta}$ as cathode materials, and $\mathrm{La}_{0.4} \mathrm{Ce}_{0.6} \mathrm{O}_{2-\delta}$ (LDC) as the buffer layer between the anode and the electrolyte in order to prevent the interdiffusion of ionic species. $\mathrm{SMFO}, \mathrm{Sr}_{0.7} \mathrm{~Tb}_{0.3} \mathrm{CoO}_{3-\delta}, \mathrm{Sr}_{0.7} \mathrm{Er}_{0.3} \mathrm{CoO}_{3-\delta}$, and LDC inks were prepared with terpineol. The working electrode area of the cell was 0.25 $\mathrm{cm}^{2}(0.5 \times 0.5 \mathrm{~cm})$. Pt gauze with a small amount of Pt paste was used as current collector at both the anodic and the cathodic sides for ensuring electrical contact. The single cell was sealed onto one end of an alumina tube with glass paste and then placed in a vertical furnace. Hydrogen was directly supplied to the anode surface and air to the cathode surface. Before testing, the anode was exposed to $5 \% \mathrm{H}_{2} / \mathrm{N}_{2}$ for 2 hours from 25 to $850^{\circ} \mathrm{C}$ and then fed with pure hydrogen for 15 min at $850^{\circ} \mathrm{C}$. The fuel-cell tests were performed with an AUTOLAB $302 \mathrm{~N}$ potentiostat/galvanostat by changing the voltage of the cell from the OCV ("Open current voltage") to $0.1 \mathrm{~V}$, with steps of $0.010 \mathrm{~V}$, holding 10 seconds at each step. Current density was calculated by the recorded current flux through the effective area of the cell $\left(0.25 \mathrm{~cm}^{2}\right)$.

\section{Results and Discussion}

Crystallographic characterization.-The crystal-structure refinement was performed from high resolution NPD data collected at the $\mathrm{D} 2 \mathrm{~B}$ diffractometer at room temperature (RT) for $\mathrm{Sr}_{0.7} \mathrm{~Tb}_{0.3} \mathrm{CoO}_{3-\delta}$ and $\mathrm{Sr}_{0.7} \mathrm{Er}_{0.3} \mathrm{CoO}_{3-\delta}$ and at $200,400,600$ and $800^{\circ} \mathrm{C}$ for $\mathrm{Sr}_{0.7} \mathrm{~Tb}_{0.3} \mathrm{CoO}_{3-\delta}$. The crystal structures were refined in the space group $\mathrm{I} 4 / \mathrm{mmm}$ (No. 139), with $Z=16$, based on the model described for $\mathrm{Sr}_{0.7} \mathrm{Y}_{0.3} \mathrm{CoO}_{3-\delta}{ }^{23-25}$ Initially, $\mathrm{Sr}$ and $\mathrm{Tb}$ or Er were distributed at random over three crystallographic sites, $4 e, 8 g$ and $4 e$, with occupancy factors $0.7 / 0.3$. However, a model allowing long range ordering of part of $\mathrm{Sr}$ and $\mathrm{R},{ }^{26,27}$ gave better results.

Despite the quite similar $\mathrm{Sr} / \mathrm{Tb}$ or $\mathrm{Sr} / \mathrm{Er}$ scattering lengths, in our final model we found that $\mathrm{Sr} 1$ and $\mathrm{Tb} 1$ or $\mathrm{Er} 1$ atoms are ordered at two different $4 e(0,0, \mathrm{z})$ sites whereas $(\mathrm{Sr}, \mathrm{Tb}) 2$ or $(\mathrm{Sr}, \mathrm{Er}) 2$ are distributed at random at $8 g\left(0, \frac{1}{2}, \mathrm{z}\right)$. Two non-equivalent $\mathrm{Co}$ atoms are placed at $8 h(\mathrm{x}, \mathrm{x}, 0)(\mathrm{Co} 1)$ and $8 f\left(\frac{1}{4}, \frac{1}{4}, \frac{1}{4}\right)(\mathrm{Co} 2)$. The axial oxygen atoms $\mathrm{O} 2$ are located at $16 \mathrm{~m}(\mathrm{x}, \mathrm{x}, \mathrm{z})$, whereas the equatorial oxygens $\mathrm{O} 1, \mathrm{O} 3$ and $\mathrm{O} 4$ occupy the $16 n(0, \mathrm{y}, \mathrm{z}), 8 i(\mathrm{x}, 0,0)$ and $8 j\left(\mathrm{x}, \frac{1}{2}, 0\right)$ Wyckoff positions, respectively.

In order to determine the stoichiometric formula, the occupancy factor for all the oxygen $(\mathrm{O} 1, \mathrm{O} 2, \mathrm{O} 3$ and $\mathrm{O} 4)$ atoms was also refined. $\mathrm{O} 1$ and $\mathrm{O} 2$ occupancies were fixed to unity since they converged to values close to 1 for $\mathrm{Sr}_{0.7} \mathrm{Er}_{0.3} \mathrm{CoO}_{3-\delta}$ whereas $\mathrm{O} 1$ was only fixed to unity in the case of $\mathrm{Sr}_{0.7} \mathrm{~Tb}_{0.3} \mathrm{CoO}_{3-\delta} \mathrm{O} 3$ converged to values slightly lower than 1 and $\mathrm{O} 4$ reveals an important number of vacancies for both compounds. Table I gathers the unit-cell parameters, atomic positions, occupancies, displacement parameters, discrepancy factors and selected interatomic distances after the Rietveld refinements of the crystal structure at room temperature. The unit-cell parameters of $\mathrm{Sr}_{0.7} \mathrm{R}_{0.3} \mathrm{CoO}_{3-\delta}(\mathrm{R}=\mathrm{Er}$ and $\mathrm{Tb})$ increase with the ionic radius of the trivalent rare-earth ion $\left(\mathrm{Er}^{3+}: 1.004 \AA\right.$; $\left.\mathrm{Tb}^{3+}=1.040 \AA\right)$ in eightfold coordination. ${ }^{28}$ On the basis of the obtained occupancy factors for 
Table I. Unit-cell parameters, atomic positions, occupancies, displacement parameters, reliability factors and selected atomic distances $(\AA)$ of $\mathrm{Sr}_{0.7} \mathrm{Er}_{0.3} \mathrm{CoO}_{3-\delta}$ and $\mathrm{Sr}_{0.7} \mathrm{~Tb}_{0.3} \mathrm{CoO}_{3-\delta}$ in the tetragonal $I 4 / \mathrm{mmm}$ (no. 139) space group, $Z=16$, from NPD data at $25^{\circ} \mathrm{C}$.

\begin{tabular}{|c|c|c|}
\hline $\mathrm{Sr}_{0.7} \mathrm{R}_{0.3} \mathrm{CoO}_{3-\delta}$ & Er & $\mathrm{Tb}$ \\
\hline $\mathrm{a}(\AA)$ & $7.6240(1)$ & $7.6366(1)$ \\
\hline $\mathrm{b}(\AA)$ & $7.6240(1)$ & $7.6366(1)$ \\
\hline$c(\AA)$ & $15.3048(5)$ & $15.3563(4)$ \\
\hline$V\left(\AA^{3}\right)$ & $889.29(2)$ & $895.55(3)$ \\
\hline \multicolumn{3}{|l|}{$\operatorname{Sr} 14 \mathrm{e}(0,0, \mathrm{z})$} \\
\hline $\mathrm{z}$ & $0.87507(4)$ & $0.87541(4)$ \\
\hline $\mathrm{B}_{\text {iso }}\left(\AA^{2}\right)$ & $0.73(1)$ & $0.93(1)$ \\
\hline $\mathrm{f}_{\mathrm{occ}} \mathrm{Sr}$ & 1.00 & 1.00 \\
\hline \multicolumn{3}{|l|}{$\mathrm{R} 14 \mathrm{e}(0,0, \mathrm{z})$} \\
\hline $\mathrm{z}$ & $0.34870(4)$ & $0.35146(4)$ \\
\hline $\mathrm{B}_{\text {iso }}\left(\AA^{2}\right)$ & $1.68(1)$ & $1.68(1)$ \\
\hline $\mathrm{f}_{\mathrm{occ}} \mathrm{R}$ & 1.00 & 1.00 \\
\hline \multicolumn{3}{|l|}{$(\mathrm{Sr}, \mathrm{R}) 28 \mathrm{~g}(0,1 / 2, \mathrm{z})$} \\
\hline $\mathrm{z}$ & $0.86998(3)$ & $0.86900(2)$ \\
\hline $\mathrm{B}_{\text {iso }}\left(\AA^{2}\right)$ & $1.526(9)$ & $1.214(7)$ \\
\hline $\mathrm{f}_{\mathrm{occ}}(\mathrm{Sr} / \mathrm{R})$ & $0.90 / 0.10$ & $0.90 / 0.10$ \\
\hline \multicolumn{3}{|l|}{ Co1 8h $(\mathrm{x}, \mathrm{x}, 0)$} \\
\hline $\mathrm{x}$ & $0.74977(9)$ & $0.75100(7)$ \\
\hline $\mathrm{B}_{\text {iso }}\left(\AA^{2}\right)$ & $1.56(2)$ & $1.30(1)$ \\
\hline $\mathrm{f}_{\mathrm{occ}} \mathrm{Co} 1$ & 1.00 & 1.00 \\
\hline \multicolumn{3}{|l|}{$\mathrm{Co} 2$ \&f $\left(\frac{1}{4}, \frac{1}{4}, \frac{1}{4}\right)$} \\
\hline$B_{\text {iso }}\left(\AA^{2}\right)$ & $0.42(1)$ & $0.46(1)$ \\
\hline $\mathrm{f}_{\mathrm{occ}} \mathrm{Co} 2$ & 1.00 & 1.00 \\
\hline \multicolumn{3}{|l|}{ O1 16n $(0, y, z)$} \\
\hline $\mathrm{y}$ & $0.26074(4)$ & $0.25993(4)$ \\
\hline $\mathrm{z}$ & $0.23970(2)$ & $0.24126(2)$ \\
\hline $\mathrm{B}_{\text {iso }}\left(\AA^{2}\right)$ & $0.784(8)$ & $0.549(6)$ \\
\hline $\mathrm{f}_{\mathrm{occ}}$ & 1.00 & $0.978(1)$ \\
\hline \multicolumn{3}{|l|}{$\mathrm{O} 216 \mathrm{~m}(\mathrm{x}, \mathrm{x}, \mathrm{z})$} \\
\hline $\mathrm{x}$ & $0.28866(2)$ & $0.28583(2)$ \\
\hline $\mathrm{z}$ & $0.11466(3)$ & $0.11642(2)$ \\
\hline $\mathrm{B}_{\text {iso }}\left(\AA^{2}\right)$ & $1.667(7)$ & $2.159(7)$ \\
\hline $\mathrm{f}_{\mathrm{occ}}$ & 1.00 & 1.00 \\
\hline \multicolumn{3}{|l|}{$\mathrm{O} 38 \mathrm{i}(\mathrm{x}, 0,0)$} \\
\hline $\mathrm{x}$ & $0.75775(8)$ & $0.75530(8)$ \\
\hline $\mathrm{B}_{\text {iso }}\left(\AA^{2}\right)$ & $1.49(1)$ & $2.60(1)$ \\
\hline $\mathrm{f}_{\mathrm{occ}}$ & $0.916(1)$ & $0.956(1)$ \\
\hline \multicolumn{3}{|l|}{$\mathrm{O} 48 \mathrm{j}(\mathrm{x}, 1 / 2,0)$} \\
\hline $\mathrm{x}$ & $0.3660(1)$ & $0.3547(1)$ \\
\hline $\mathrm{B}_{\mathrm{eq}}\left(\AA^{2}\right)$ & 6.5346 & 8.5077 \\
\hline$\beta_{11}^{*}$ & $188(0)$ & $477(41)$ \\
\hline$\beta_{22}{ }^{*}$ & $516(52)$ & $363(36)$ \\
\hline$\beta_{33}{ }^{*}$ & $34(8)$ & $63(9)$ \\
\hline $\mathrm{f}_{\mathrm{occ}}$ & $0.648(1)$ & $0.728(1)$ \\
\hline \multicolumn{3}{|l|}{ Reliability factors } \\
\hline$x^{2}$ & 3.74 & 2.15 \\
\hline $\mathrm{R}_{\mathrm{p}}(\%)$ & 2.98 & 3.04 \\
\hline $\mathrm{R}_{\mathrm{wp}}(\%)$ & 3.85 & 3.85 \\
\hline $\mathrm{R}_{\exp }(\%)$ & 1.99 & 2.63 \\
\hline $\mathrm{R}_{\text {Bragg }}(\%)$ & 5.29 & 5.77 \\
\hline \multicolumn{3}{|l|}{ Distances $(\AA)$} \\
\hline $\mathrm{Co} 1-\mathrm{O} 2(\mathrm{x} 2)$ & $1.8027(5)$ & $1.8315(5)$ \\
\hline Co1-O3 (x2) & $1.9087(7)$ & $1.9018(6)$ \\
\hline $\mathrm{Co} 1-\mathrm{O} 4(\mathrm{x} 2)$ & $2.1040(9)$ & $2.0797(8)$ \\
\hline $\mathrm{Co} 2-\mathrm{O} 1(\mathrm{x} 4)$ & $1.9143(4)$ & $1.9154(3)$ \\
\hline $\mathrm{Co} 2-\mathrm{O} 2(\mathrm{x} 2)$ & $2.1124(5)$ & $2.0875(5)$ \\
\hline
\end{tabular}

${ }^{*}$ Anisotropic Betas $\left(x 10^{4}\right) \cdot \beta_{12}=\beta_{23}=\beta_{13}=0$.

oxygen positions, the chemical formulae at $\mathrm{RT}$ are $\mathrm{Sr}_{0.7} \mathrm{Er}_{0.3} \mathrm{CoO}_{2.78(1)}$ and $\mathrm{Sr}_{0.7} \mathrm{~Tb}_{0.3} \mathrm{CoO}_{2.82(1)}$. Taking in account the oxygen vacancies observed at room temperature, and assuming divalent and trivalent oxi-

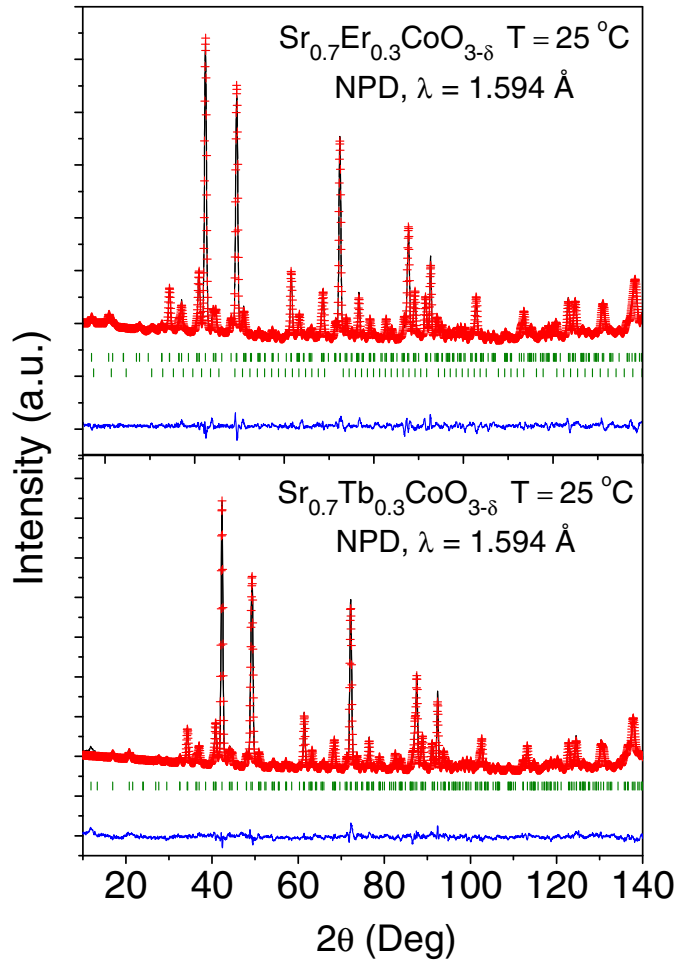

Figure 1. Observed (red crosses), calculated (black line) and difference (bottom line) NPD Rietveld profiles at RT for $\mathrm{Sr}_{0.7} \mathrm{Er}_{0.3} \mathrm{CoO}_{3-\delta}$ and $\mathrm{Sr}_{0.7} \mathrm{~Tb}_{0.3} \mathrm{CoO}_{3-\delta}$. The two series of markers correspond to the positions of the allowed Bragg reflections for the crystallographic phase and the $\mathrm{Er}_{2} \mathrm{O}_{3}$ impurity.

dation states for $\mathrm{Sr}$ and $\mathrm{R}$ ions, respectively, a Co valence of $\mathrm{Co}^{3.26+}$ for $\mathrm{R}=\mathrm{Er}$ and $\mathrm{Co}^{3.34+}$ for $\mathrm{R}=\mathrm{Tb}$ was determined, indicating a mixed valence $\mathrm{Co}^{3+}-\mathrm{Co}^{4+}$. It is important to consider also impact of the presence of a certain mixed valence $\mathrm{Tb}^{3+}-\mathrm{Tb}^{4+}$ that would lead to a higher oxygen content in this compound. Figure 1 illustrates the good agreement between the observed and calculated NPD patterns for $\mathrm{Sr}_{0.7} \mathrm{R}_{0.3} \mathrm{CoO}_{3-\delta}(\mathrm{R}=\mathrm{Er}$ and $\mathrm{Tb})$ at room temperature. In the $\mathrm{Sr}_{0.7} \mathrm{Er}_{0.3} \mathrm{CoO}_{3-\delta}$ diagram, a small amount of $\mathrm{Er}_{2} \mathrm{O}_{3}$ impurity was detected. Probably, this impurity is formed due to the evaporation at high temperature of $\mathrm{Co}_{3} \mathrm{O}_{4}$. A similar situation has also been reported in the literature for the Y-doped material. ${ }^{23}$ This impurity is represented by the second series of markers in the diagram. From the scale factors, the $\mathrm{Er}_{2} \mathrm{O}_{3}$ impurity was estimated to be $\sim 4 \mathrm{wt} \%$.

The crystal structure of $\mathrm{Sr}_{0.7} \mathrm{R}_{0.3} \mathrm{CoO}_{3-\delta}(\mathrm{R}=\mathrm{Er}$ and $\mathrm{Tb})$ is illustrated in Figure 2. This structure is formed by $\mathrm{CoO}_{4}$ tetrahedral layers containing $\mathrm{Co} 1$ atoms that alternate with tilted $\mathrm{CoO}_{6}$ octahedral layers containing $\mathrm{Co} 2$ atoms. The tetrahedral layer is an oxygen- deficient layer that consists of four $\mathrm{CoO}_{4}$ tetrahedral groups, where each tetrahedron shares two oxygen atoms (O3) with the adjacent tetrahedron. Octahedral and tetrahedral layers share oxygen atoms (O2). Finally, extra oxygen atoms $(\mathrm{O} 4)$ are situated in the tetrahedral layers, incrementing its coordination in fully-disordered half-occupied positions.

Table I also contains the main interatomic distances of the compounds at room temperature. The $\mathrm{Co} \mathrm{O}_{4}$ groups in the oxygendeficient layers are compressed along the $c$ axis with a shorter Co1-O2 distance than the $\mathrm{Co} 1-\mathrm{O} 3$ distance in the $a b$ plane, which is much larger. The Co1-O4 bond length is extremely large suggesting that the bond is very weak and indicating an extremely high lability for this oxygen atom. On the other hand, the $\mathrm{CoO}_{6}$ groups that belong to the octahedral layers, have a significant axial distortion with four shorter equatorial Co2-O1 distances and two longer $\mathrm{Co} 2-\mathrm{O} 2$ axial distances as shown in Table I. Furthermore, the thermal factors for $\mathrm{O} 4$ atoms show unusually high $\mathrm{B}_{\mathrm{eq}}$ values indicating that $\mathrm{O} 4$ atoms become mobile and disordered; an anisotropic refinement of $\mathrm{O} 4$ displacement 


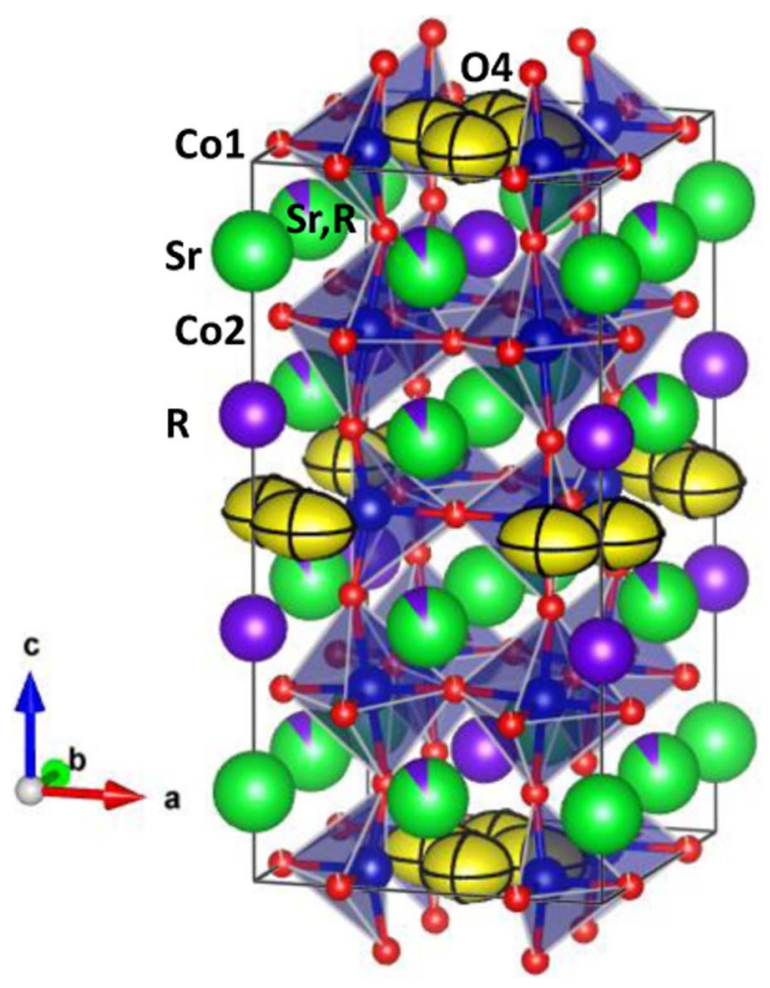

Figure 2. Crystal structure of the oxygen-deficient perovskite $\mathrm{Sr}_{0.7} \mathrm{R}_{0.3} \mathrm{CoO}_{3-\delta}$. O1, O2, O3 atoms (red spheres), O4 (yellow ellipsoids), $\mathrm{Sr}$ (green spheres) and $\mathrm{R}=\mathrm{Tb}, \mathrm{Er}$ (purple spheres) and $\mathrm{Co} 1, \mathrm{Co} 2$ atoms (blue spheres).

parameters (Table I) indicate rather elongated ellipsoids giving a hint for the $\mathrm{O} 4$ diffusion and delocalization in the tetrahedral layers. This diffusion has an important role in the ionic conduction of oxide ions, which is an essential ingredient in MIEC-type oxides.

The thermal evolution of the crystal structure under the cathode conditions of a SOFC in air was studied by NPD for $\mathrm{R}=\mathrm{Tb}$. The NPD patterns are illustrated in Figure 3. No structural transitions in the temperature range under study $\left(25-800^{\circ} \mathrm{C}\right)$ were found. The crystal structure for the compound was always defined in the $14 / \mathrm{mmm}$ space group.

Figure 4 illustrates the excellent fit between the observed and calculated NPD pattern for $\mathrm{R}=\mathrm{Tb}$ at 400 and $800^{\circ} \mathrm{C}$. The irregular

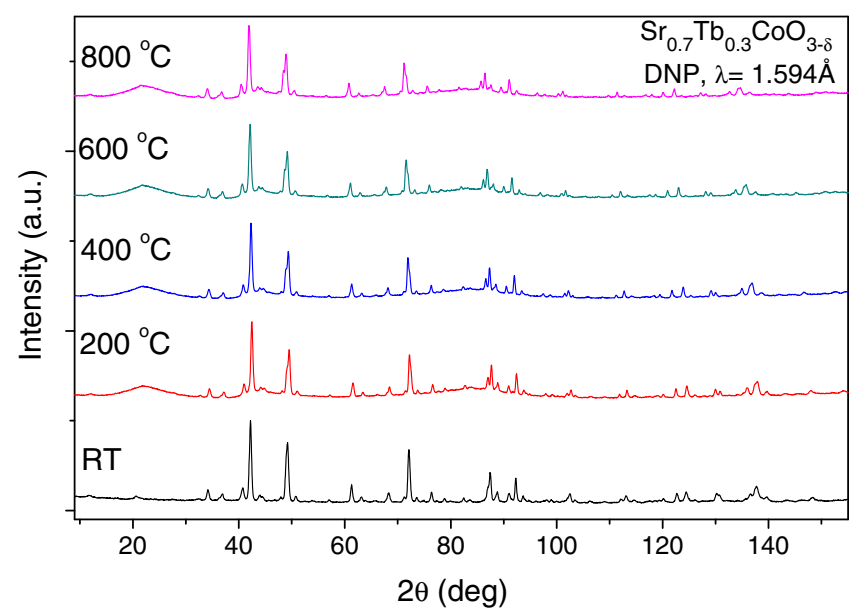

Figure 3. Thermal evolution of the NPD patterns for $\mathrm{Sr}_{0.7} \mathrm{~Tb}_{0.3} \mathrm{CoO}_{3-\delta}$ between RT and $800^{\circ} \mathrm{C}$.

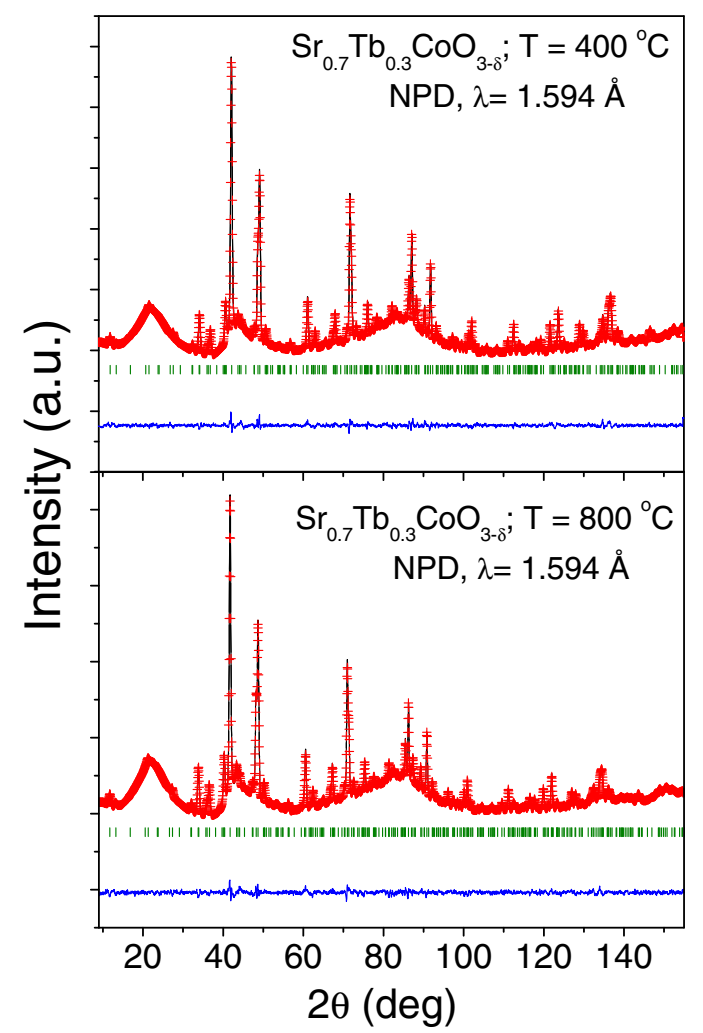

Figure 4. Observed (crosses), calculated (full line) and difference (at the bottom) NPD profiles for $\mathrm{Sr}_{0.7} \mathrm{~Tb}_{0.3} \mathrm{CoO}_{3-\delta}$ at 400 and $800^{\circ} \mathrm{C}$ in air refined in the tetragonal $14 / \mathrm{mmm}$ space group. The vertical markers correspond to the allowed Bragg reflections.

background comes from the quartz container used to allow the sample to be in contact with the air during the heating of the sample in a vanadium furnace internally working under high vacuum. The results from the refinement at the different temperatures for this oxide are listed in Table II.

Figure 5a shows the temperature variation of the unit-cell parameters (left axis) and volume (right axis) for $\mathrm{Sr}_{0.7} \mathrm{~Tb}_{0.3} \mathrm{CoO}_{3-\delta}$. The unitcell parameters and volume increase when the sample is heated due to the expansion of the chemical bonds. As the sample is heated, the volume increases from $895.55 \AA^{3}$ to $932.43 \AA^{3}$ at $800^{\circ} \mathrm{C}$ (Fig 5a right axis). The thermal evolution of the oxygen content and anisotropic displacement factors $\left(\mathrm{B}_{\text {eq }}\right)$ of the $\mathrm{O} 4$ oxygen atoms in air were also studied by neutron diffraction.

Figure $5 \mathrm{~b}$ (left axis) illustrates the temperature variation of the oxygen-vacancy concentration for $\mathrm{Sr}_{0.7} \mathrm{~Tb}_{0.3} \mathrm{CoO}_{3-\delta}$. The oxygen content decreases when heating the sample in air from $\mathrm{Sr}_{0.7} \mathrm{~Tb}_{0.3} \mathrm{CoO}_{2.82(1)}$ at $25^{\circ} \mathrm{C}$ to $\mathrm{Sr}_{0.7} \mathrm{~Tb}_{0.3} \mathrm{CoO}_{2.67(1)}$ at $800^{\circ} \mathrm{C}$. The number of oxygen vacancies considerably increases with the temperature yielding an oxidation state of $\mathrm{Co}^{3.04+}$ at $800^{\circ} \mathrm{C}$ (assuming trivalent $\mathrm{Tb}$ at this temperature). This abundant amount of oxygen vacancies observed at high temperature, due to the reduction from $\mathrm{Tb}^{3+, 4+}$ to $\mathrm{Tb}^{3+}$, is essential for promoting the $\mathrm{O}^{2-}$ ions movement required in a MIEC oxide. Figure $5 \mathrm{~b}$ (right axis) shows the anisotropic displacement parameters $\left(\mathrm{B}_{\mathrm{eq}}\right)$ of the $\mathrm{O} 4$ oxygen atoms that increase as the temperature increases, giving a value of $11.1 \AA^{2}$ at $800^{\circ} \mathrm{C}$. In addition, it is interesting to note that the anisotropic refinement of the $\mathrm{O} 4$ positions, affected by this huge displacement factor in the ab plane at $800^{\circ} \mathrm{C}$, show distinct ellipsoid semiaxes suggesting a rather anisotropic vibration for $\mathrm{O} 4$, as represented in Figure 2. The oxygen atoms with this enormous $B_{\text {eq }}$ value are expected to display a high mobility, providing the material with a high ionic conductivity at the working temperature of the SOFC. 
Table II. Unit-cell, thermal parameters and selected distances $\left(\stackrel{\AA}{)}\right.$ ) for $\mathrm{Sr}_{0.7} \mathrm{~Tb}_{0.3} \mathrm{CoO}_{3-\delta}$ in the tetragonal I4/mmm space group, from NPD from 25 to $800^{\circ} \mathrm{C}$.

\begin{tabular}{|c|c|c|c|c|c|}
\hline $\mathrm{Sr}_{0.7} \mathrm{~Tb}_{0.3} \mathrm{CoO}_{3-\delta}$ & 25 & 200 & 400 & 600 & 800 \\
\hline $\mathrm{a}(\AA)$ & $7.6366(1)$ & $7.64432(8)$ & $7.66906(9)$ & $7.6988(1)$ & 7.7291(1) \\
\hline $\mathrm{b}(\AA)$ & $7.6366(1)$ & $7.64432(8)$ & $7.66906(9)$ & $7.6988(1)$ & 7.7291(1) \\
\hline c $(\AA)$ & $15.3563(4)$ & $15.4144(2)$ & $15.4728(2)$ & $15.5409(2)$ & $15.6084(3)$ \\
\hline $\mathrm{V}\left(\AA^{3}\right)$ & $895.55(3)$ & $900.75(1)$ & $910.02(2)$ & $921.14(2)$ & $932.43(3)$ \\
\hline \multicolumn{6}{|l|}{$\operatorname{Sr} 14 \mathrm{e}(0,0, \mathrm{z})$} \\
\hline $\mathrm{z}$ & $0.87541(4)$ & $0.87765(4)$ & $0.87742(6)$ & $0.87612(6)$ & $0.87645(6)$ \\
\hline $\mathrm{B}_{\text {iso }}\left(\AA^{2}\right)$ & $0.93(1)$ & 1.61(1) & $2.40(1)$ & $2.88(1)$ & $3.44(1)$ \\
\hline $\mathrm{f}_{\mathrm{occ}} \mathrm{Sr}$ & 1.00 & 1.00 & 1.00 & 1.00 & 1.00 \\
\hline \multicolumn{6}{|l|}{$\mathrm{Tb} 14 \mathrm{e}(0,0, \mathrm{z})$} \\
\hline $\mathrm{z}$ & $0.35146(4)$ & $0.35431(3)$ & $0.35491(3)$ & $0.35413(3)$ & $0.35477(3)$ \\
\hline $\mathrm{B}_{\text {iso }}\left(\AA^{2}\right)$ & $1.68(1)$ & $1.081(8)$ & $1.304(9)$ & $1.493(9)$ & $1.66(1)$ \\
\hline $\mathrm{f}_{\mathrm{occ}} \mathrm{Tb}$ & 1.00 & 1.00 & 1.00 & 1.00 & 1.00 \\
\hline \multicolumn{6}{|l|}{$(\mathrm{Sr}, \mathrm{Tb}) 28 \mathrm{~g}(0,1 / 2, \mathrm{z})$} \\
\hline $\mathrm{Z}$ & $0.86900(2)$ & $0.86873(2)$ & $0.86859(2)$ & $0.86840(2)$ & $0.86827(3)$ \\
\hline $\mathrm{B}_{\text {iso }}\left(\AA^{2}\right)$ & $1.214(7)$ & $1.025(5)$ & $1.313(6)$ & $1.747(6)$ & $2.177(8)$ \\
\hline $\mathrm{f}_{\mathrm{occ}}(\mathrm{Sr} / \mathrm{Tb})$ & $0.90 / 0.10$ & $0.90 / 0.10$ & $0.90 / 0.10$ & $0.90 / 0.10$ & $0.90 / 0.10$ \\
\hline \multicolumn{6}{|l|}{ Co1 8h (x, x, 0) } \\
\hline $\mathrm{x}$ & $0.75100(7)$ & $0.75072(6)$ & $0.74868(7)$ & $0.74874(7)$ & $0.74589(8)$ \\
\hline$B_{\text {iso }}\left(\AA^{2}\right)$ & $1.30(1)$ & 1.41(1) & $1.51(1)$ & $1.97(1)$ & $2.58(1)$ \\
\hline $\mathrm{f}_{\mathrm{occ}} \mathrm{Co} 1$ & 1.00 & 1.00 & 1.00 & 1.00 & 1.00 \\
\hline \multicolumn{6}{|l|}{$\operatorname{Co} 28 f\left(\frac{1}{4}, \frac{1}{4}, \frac{1}{4}\right)$} \\
\hline $\mathrm{B}_{\text {iso }}\left(\AA^{2}\right)$ & $0.46(1)$ & $0.587(8)$ & $0.970(9)$ & $1.254(9)$ & $1.71(1)$ \\
\hline $\mathrm{f}_{\mathrm{occ}} \mathrm{Co} 2$ & 1.00 & 1.00 & 1.00 & 1.00 & 1.00 \\
\hline \multicolumn{6}{|l|}{ O1 16n $(0, y, z)$} \\
\hline $\mathrm{y}$ & $0.25993(4)$ & $0.24660(3)$ & $0.24752(4)$ & $0.24701(4)$ & $0.24722(5)$ \\
\hline $\mathrm{z}$ & $0.24126(2)$ & $0.24082(2)$ & $0.24097(2)$ & $0.24025(2)$ & $0.24028(2)$ \\
\hline $\mathrm{B}_{\text {iso }}\left(\AA^{2}\right)$ & $0.549(6)$ & $1.065(4)$ & $1.420(5)$ & $1.761(5)$ & $2.110(6)$ \\
\hline $\mathrm{f}_{\mathrm{occ}}$ & $0.978(1)$ & 1.00 & 1.00 & 1.00 & 1.00 \\
\hline \multicolumn{6}{|l|}{$\mathrm{O} 216 \mathrm{~m}(\mathrm{x}, \mathrm{x}, \mathrm{z})$} \\
\hline $\mathrm{x}$ & $0.28583(2)$ & $0.28173(2)$ & $0.28161(2)$ & $0.28351(2)$ & $0.28474(3)$ \\
\hline $\mathrm{z}$ & $0.11642(2)$ & $0.11804(2)$ & $0.11738(2)$ & $0.11656(2)$ & $0.11611(2)$ \\
\hline $\mathrm{B}_{\text {iso }}\left(\AA^{2}\right)$ & $2.159(7)$ & $2.510(9)$ & $3.20(1)$ & $3.45(1)$ & $3.85(1)$ \\
\hline $\mathrm{f}_{\mathrm{occ}}$ & 1.00 & 1.00 & 1.00 & $0.990(1)$ & $0.971(1)$ \\
\hline \multicolumn{6}{|l|}{$\mathrm{O} 38 \mathrm{i}(\mathrm{x}, 0,0)$} \\
\hline $\mathrm{x}$ & $0.75530(8)$ & $0.72004(6)$ & $0.71988(6)$ & $0.71866(6)$ & $0.71737(8)$ \\
\hline $\mathrm{B}_{\text {iso }}\left(\AA^{2}\right)$ & $2.60(1)$ & $2.23(1)$ & $2.24(1)$ & $2.65(1)$ & $3.42(1)$ \\
\hline $\mathrm{f}_{\mathrm{occ}}$ & $0.956(1)$ & 1.00 & $0.988(1)$ & $0.988(1)$ & $0.974(1)$ \\
\hline \multicolumn{6}{|l|}{$\mathrm{O} 48 \mathrm{j}(\mathrm{x}, 1 / 2,0)$} \\
\hline $\mathrm{x}$ & $0.3547(1)$ & $0.3551(2)$ & $0.3573(2)$ & $0.3642(1)$ & $0.3735(2)$ \\
\hline $\mathrm{B}_{\mathrm{eq}}\left(\AA^{2}\right)$ & 7.51 & 7.87 & 8.84 & 9.57 & 11.12 \\
\hline$\beta_{11}{ }^{*}$ & $477(41)$ & $525(50)$ & $616(68)$ & 423(49) & $687(91)$ \\
\hline$\beta_{22} *$ & $363(36)$ & $303(34)$ & $373(44)$ & $336(38)$ & $430(58)$ \\
\hline$\beta_{33}{ }^{*}$ & $63(9)$ & $45(9)$ & $34(8)$ & $49(9)$ & $68(13)$ \\
\hline$f_{o c c}$ & $0.728(1)$ & $0.492(1)$ & $0.468(2)$ & $0.444(1)$ & $0.436(1)$ \\
\hline \multicolumn{6}{|l|}{ Reliability factors } \\
\hline$x^{2}$ & 2.15 & 1.77 & 1.76 & 1.50 & 1.56 \\
\hline$\hat{\mathrm{R}_{\mathrm{p}}(\%)}$ & 3.04 & 1.29 & 1.27 & 1.18 & 1.23 \\
\hline $\mathrm{R}_{\mathrm{wp}}(\%)$ & 3.85 & 1.66 & 1.65 & 1.52 & 1.55 \\
\hline $\mathrm{R}_{\exp }(\%)$ & 2.63 & 1.25 & 1.24 & 1.24 & 1.24 \\
\hline $\mathrm{R}_{\text {Bragg }}(\%)$ & 5.77 & 4.07 & 5.13 & 4.81 & 5.63 \\
\hline \multicolumn{6}{|l|}{ Distances $(\AA)$} \\
\hline $\mathrm{Co} 1-\mathrm{O} 2(\mathrm{x} 2)$ & $1.8315(5)$ & $1.8530(3)$ & $1.8457(3)$ & $1.8452(3)$ & $1.8427(5)$ \\
\hline Co1-O3 (x2) & $1.9018(6)$ & $1.9199(5)$ & $1.9400(5)$ & $1.9482(5)$ & $1.9759(7)$ \\
\hline $\mathrm{Co} 1-\mathrm{O} 4(\mathrm{x} 2)$ & $2.0797(8)$ & $2.0803(7)$ & $2.0731(8)$ & $2.1030(8)$ & $2.115(1)$ \\
\hline $\mathrm{Co} 2-\mathrm{O} 1(\mathrm{x} 4)$ & $1.9154(3)$ & $1.9165(3)$ & $1.9224(3)$ & $1.9308(4)$ & $1.9383(5)$ \\
\hline $\mathrm{Co} 2-\mathrm{O} 2(\mathrm{x} 2)$ & $2.0875(5)$ & $2.0628(3)$ & $2.0804(3)$ & $2.1056(3)$ & $2.1243(5)$ \\
\hline
\end{tabular}

${ }^{*}$ Anisotropic Betas $\left(x 10^{4}\right) \cdot \beta_{12}=\beta_{23}=\beta_{13}=0$.

Thermal expansion measurements.-Figure 6 shows the thermal expansion in air of the $\mathrm{Sr}_{0.7} \mathrm{R}_{0.3} \mathrm{CoO}_{3-\delta}(\mathrm{R}=\mathrm{Er}$ and $\mathrm{Tb})$ perovskites measured in order to determine the mechanical compatibility of these materials with the electrolyte. No abrupt change in the thermal expansion was observed in all the temperature range under measurement for $\mathrm{R}=\mathrm{Er}$, whose thermal expansion coefficients (TEC) measured under air atmosphere is $16.66 \times 10^{-6} \mathrm{~K}^{-1}$, while a small change in the slope at $400^{\circ} \mathrm{C}$ appeared in the case of $\mathrm{Sr}_{0.7} \mathrm{~Tb}_{0.3} \mathrm{CoO}_{3-\delta}$. This change may be related to the oxygen loss produced for the partial reduction from $\mathrm{Tb}^{3+, 4+}$ to $\mathrm{Tb}^{3+}$, according to the NPD data obtained at that temperature. In this case, thermal expansion beyond $400^{\circ} \mathrm{C}$ has a contribution of "chemical expansion". Therefore, the dilatometric analysis can be separated in two parts, the first one, from 25 to $400^{\circ} \mathrm{C}$ with a TEC value of $14.34 \times 10^{-6} \mathrm{~K}^{-1}$ and the second one, from 400 


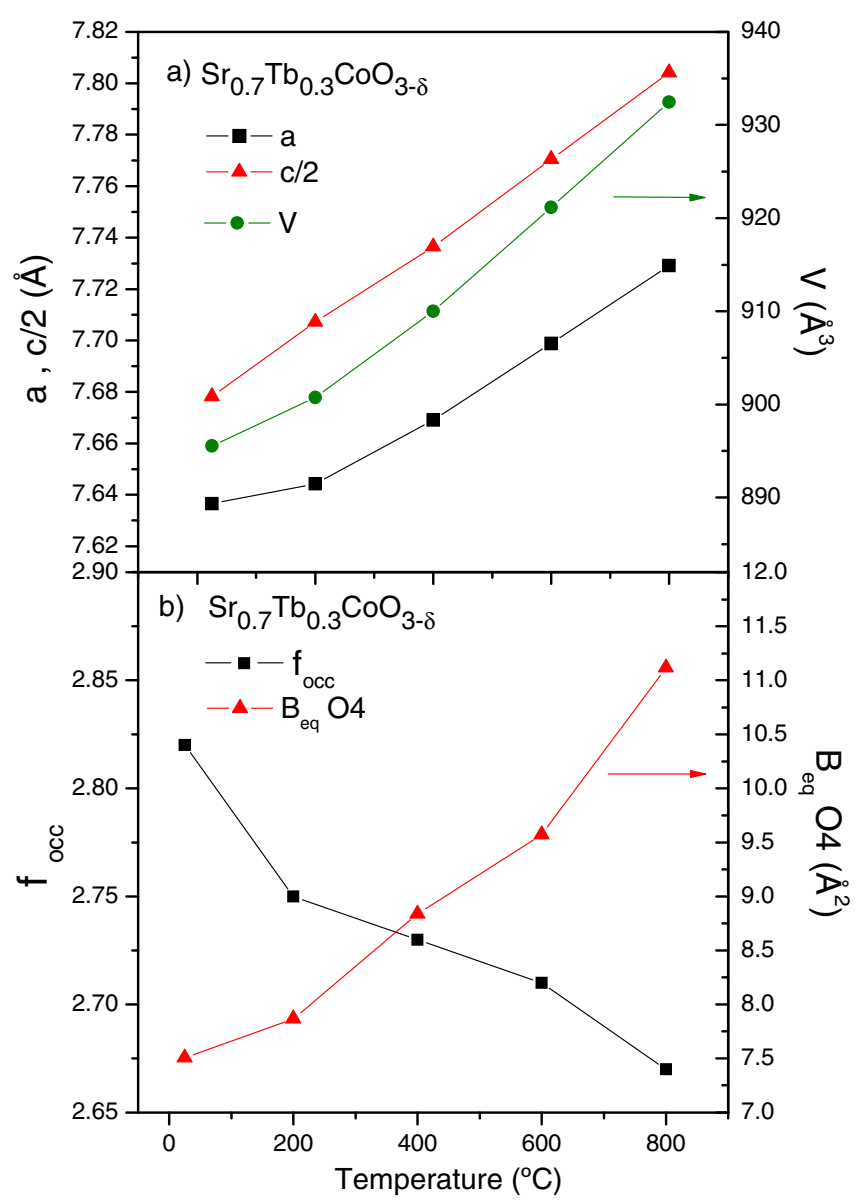

Figure 5. Thermal variation of (a) a, c/2 unit-cell parameters (left axis) and volume (right axis) and b) $\mathrm{O} 4$ occupancy factor (left axis) and $\mathrm{O} 4$ equivalent isotropic displacement factor, from in situ NPD data for $\mathrm{Sr}_{0.7} \mathrm{~Tb}_{0.3} \mathrm{CoO}_{3-\delta}$. The ESD values are as small as the symbols in the plots.

to $900^{\circ} \mathrm{C}$ with a TEC value of $18.04 \times 10^{-6} \mathrm{~K}^{-1}$ (Figure 6); we can estimate that the contribution of chemical expansion due to the partial reduction from $\mathrm{Tb}^{3+, 4+}$ to $\mathrm{Tb}^{3+}$ is around $4 \times 10^{-6} \mathrm{~K}^{-1}$ in the mentioned temperature range.

The TEC calculated for $\mathrm{Sr}_{0.7} \mathrm{~Tb}_{0.3} \mathrm{CoO}_{3-\delta}$ from the NPD data between $400-850^{\circ} \mathrm{C}$ temperature range is $18.49 \times 10^{-6} \mathrm{~K}^{-1}$, which is in concordance with that calculated by the dilatometric analysis. The

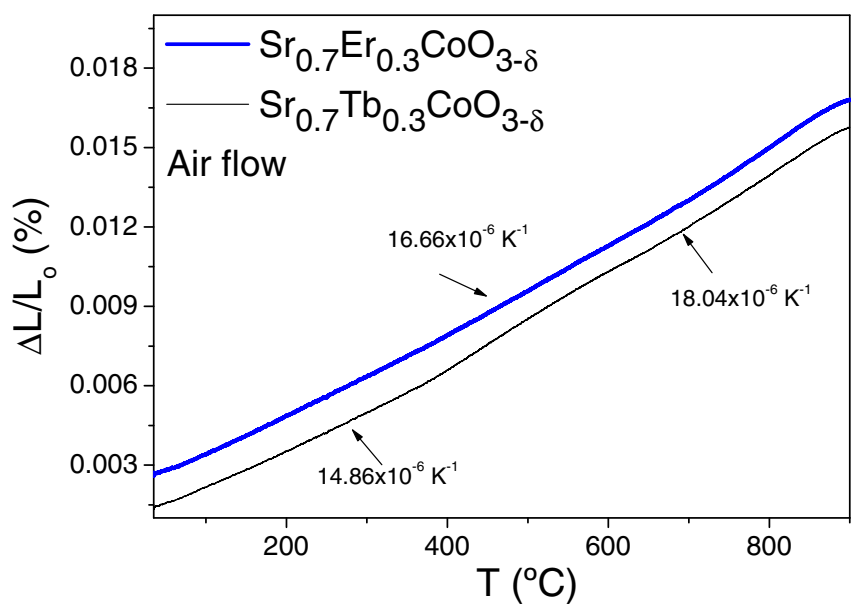

Figure 6. Thermal expansion determined by dilatometry of $\mathrm{Sr}_{0.7} \mathrm{~Tb}_{0.3} \mathrm{CoO}_{3-\delta}$ and $\mathrm{Sr}_{0.7} \mathrm{Er}_{0.3} \mathrm{CoO}_{3-\delta}$.

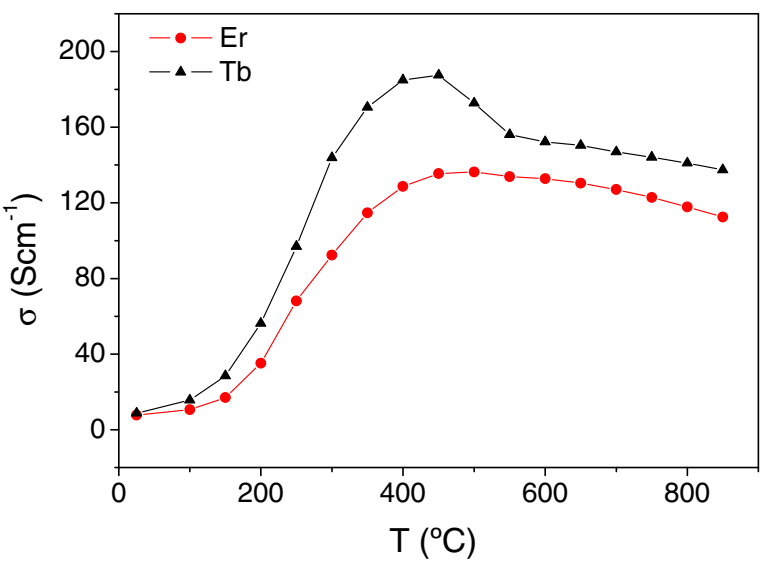

Figure 7. dc-conductivity as a function of temperature for $\mathrm{Sr}_{0.7} \mathrm{~Tb}_{0.3} \mathrm{CoO}_{3-\delta}$ and $\mathrm{Sr}_{0.7} \mathrm{Er}_{0.3} \mathrm{CoO}_{3-\delta}$.

thermal expansion coefficients obtained for $\mathrm{R}=\mathrm{Er}$ and $\mathrm{Tb}$ are significantly higher than that of the electrolyte used, which is ${ }^{29} 12.5 \times 10^{-6}$ $\mathrm{K}^{-1}$. Even though, they are inferior to those presented by other Co perovskite materials like $\mathrm{SrCo}_{0.95} \mathrm{Mo}_{0.05} \mathrm{O}_{3-\delta}$ and $\mathrm{SrCo}_{0.9} \mathrm{Sb}_{0.1} \mathrm{O}_{3-\delta}$ with $26.10 \times 10^{-6} \mathrm{~K}^{-1}$ and $21.20 \times 10^{-6} \mathrm{~K}^{-1}$ TEC values between 650 and $900^{\circ} \mathrm{C}^{10,30}$ that have been successfully used as electrode materials.

Electrical conductivity measurements.-The thermal variation of the electrical conductivity of $\mathrm{Sr}_{0.7} \mathrm{R}_{0.3} \mathrm{CoO}_{3-\delta}(\mathrm{R}=\mathrm{Er}$ and $\mathrm{Tb})$ appears in Figure 7. The samples exhibit a semiconducting behavior from 25 to $400-500^{\circ} \mathrm{C}$. From $400-500^{\circ} \mathrm{C}$, a metal-insulator transition was observed in both samples with maximum conductivities of $138 \mathrm{Scm}^{-1}$ for $\mathrm{R}=\mathrm{Tb}$ and $113 \mathrm{Scm}^{-1}$ for $\mathrm{R}=\mathrm{Er}$. This behavior was also found in $\mathrm{Sr}_{0.7} \mathrm{Ho}_{0.3} \mathrm{CoO}_{3-\delta}{ }^{15}$ and $\mathrm{SrCo}_{1-\mathrm{y}} \mathrm{Ti}_{\mathrm{y}} \mathrm{O}_{3-\delta}{ }^{31}$ systems. A change in the conductivity regime with a decrease of this magnitude can be seen about $400^{\circ} \mathrm{C}$. This alteration coincides with the change in the slope in thermal expansion measurements at the same temperature. As discussed above, this change may be due to a $\mathrm{Tb}$ partial reduction from the tetravalent to the trivalent state, with an oxygen loss and reduction of the Co valence with the concomitant loss of electronic positive defects $\left(h^{\bullet}\right)$ main charge carriers in this p-type conductors; this evolution is softened in the Er compound. For cathode materials, the usual values required in the electrical conductivity are about $100 \mathrm{Scm}^{-1}$ at the working temperature; ${ }^{32}$ therefore, the electrical conductivities of these materials are suitable for SOFC applications.

Oxygen diffusion measurements.-Oxygen tracer diffusion profiling was used to assess the oxygen self-diffusion coefficient $\left(D^{*}\right)$ and surface exchange coefficient $(k)$ in $\mathrm{Sr}_{0.7} \mathrm{~Tb}_{0.3} \mathrm{CoO}_{3-\delta}$. The normalized ${ }^{18} \mathrm{O}$ isotopic diffusion profile measured by ToF-SIMS is shown in Figure 8. A good agreement between the experimental data and the fit using Eq. 1 was observed.

The $D^{*}$ and $k$ values obtained fitting this profile (Figure 8) are $1.29 \times 10^{-10} \mathrm{~cm}^{2} \mathrm{~s}^{-1}$ and $4.83 \times 10^{-8} \mathrm{~cm}^{2} \mathrm{~s}^{-1}$, respectively, with an ${ }^{18} \mathrm{O}$ exchange for 30 minutes at $525^{\circ} \mathrm{C}$. These values are comparable with those found in the literature for good oxygen conductor cathode materials such as $\operatorname{Sr}_{0.75} \mathrm{Y}_{0.25} \mathrm{CoO}_{2.62}{ }^{33}$ ( $D^{*}=1.20$ $\times 10^{-11}$ and $k=3.45 \times 10^{-8} \mathrm{~cm}^{2} \mathrm{~s}^{-1}$ with an ${ }^{18} \mathrm{O}$ exchange for 35 minutes at $500^{\circ} \mathrm{C}$ ) and $\mathrm{La}_{0.6} \mathrm{Sr}_{0.4} \mathrm{Fe}_{0.8} \mathrm{Co}_{0.2} \mathrm{O}_{3-\delta}{ }^{34}\left(D^{*}=1.7\right.$ $\times 10^{-10}$ and $k=1.1 \times 10^{-7} \mathrm{~cm}^{2} \mathrm{~s}^{-1}$ with an ${ }^{18} \mathrm{O}$ exchange at $600^{\circ} \mathrm{C}$ ). Comparing with $\mathrm{Sr}_{0.75} \mathrm{Y}_{0.25} \mathrm{CoO}_{2.62}{ }^{33}$, the oxygen diffusion across $\mathrm{Sr}_{0.7} \mathrm{~Tb}_{0.3} \mathrm{CoO}_{3-\delta}$ is much faster, with improved oxygen reduction reaction (quantified by the $\mathrm{k}$ coefficient). On the other hand, $\mathrm{La}_{0.6} \mathrm{Sr}_{0.4} \mathrm{Fe}_{0.8} \mathrm{Co}_{0.2} \mathrm{O}_{3-\delta}{ }^{34}$ possesses similar oxygen diffusion across the material but $\mathrm{Sr}_{0.7} \mathrm{~Tb}_{0.3} \mathrm{CoO}_{3-\delta}$ has a smaller $k$ and the oxygen reduction reaction in this material is lower. The fast oxygen diffusion in this material can be correlated to the defect structure evaluated by in situ NPD. In this case, the highly mobile, hypo-stoichiometric O4 


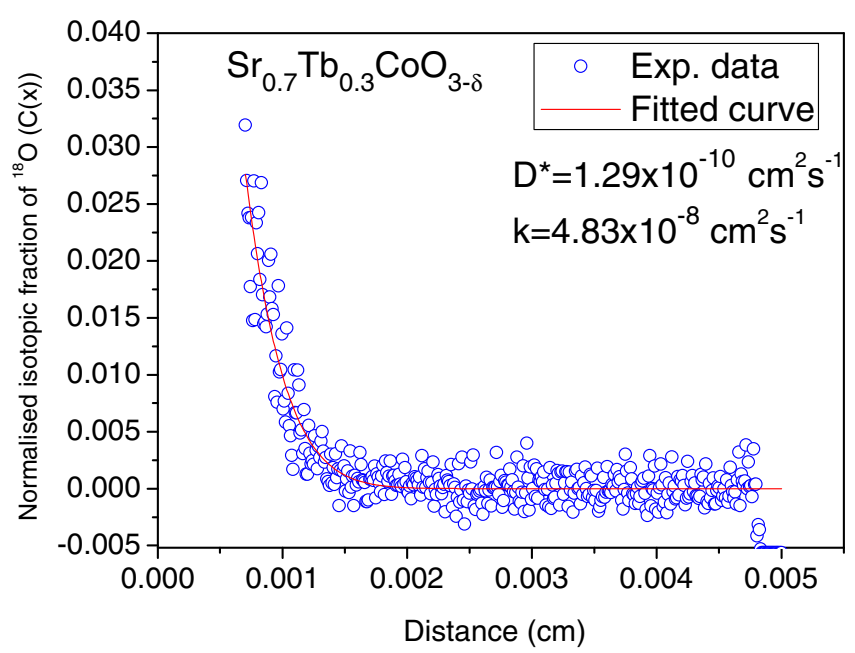

Figure 8. Normalized ${ }^{18} \mathrm{O}$ diffusion profile as measured by ToF-SIMS on $\mathrm{Sr}_{0.7} \mathrm{~Tb}_{0.3} \mathrm{CoO}_{3-\delta}$ annealed at $525^{\circ} \mathrm{C}$ for $30 \mathrm{~min}$. Solid line represents the fit to Eq. 1.

oxygen atom is suggested to be responsible for the oxygen mobility. This highlights the structural possibility that a reasonable ionic conductivity is realized in this solid. Combined with a significant electronic conductivity in a MIEC-type oxide in the working conditions of a SOFC cathode, the significant increase of the active area of the cathode is expected to improve the device performance by decreasing the polarization resistance in the air-electrode. ${ }^{33}$
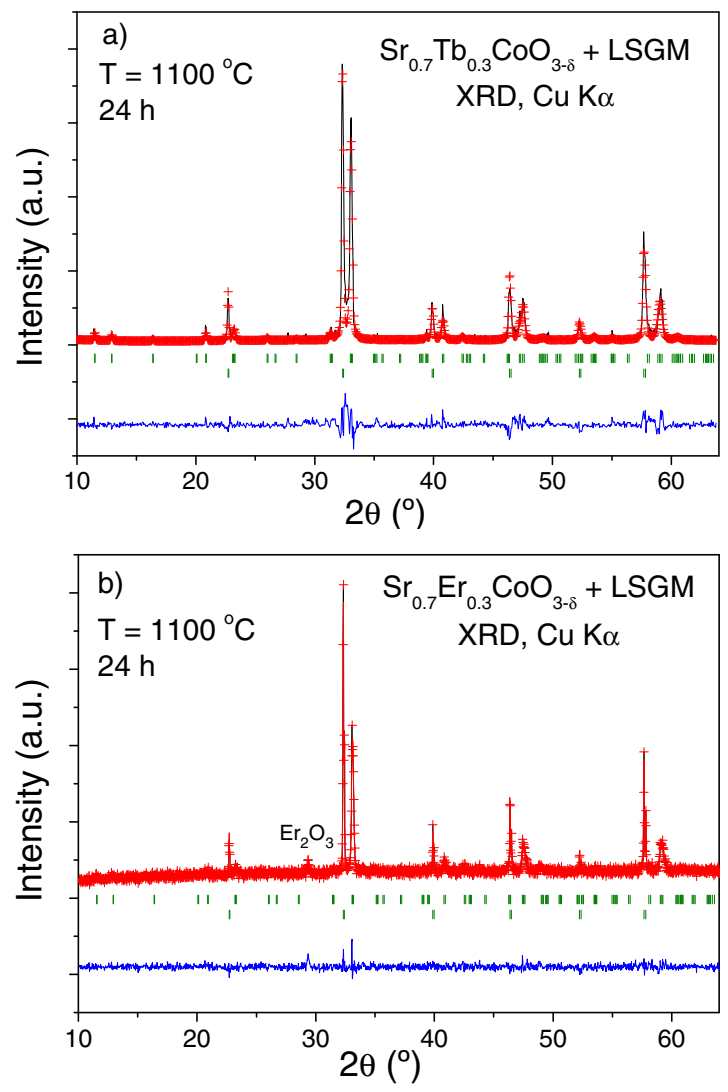

Figure 9. Rietveld-refined XRD profiles of a mixture of LSGM and a) $\mathrm{Sr}_{0.7} \mathrm{~Tb}_{0.3} \mathrm{CoO}_{3-\delta}$, b) $\mathrm{Sr}_{0.7} \mathrm{Er}_{0.3} \mathrm{CoO}_{3-\delta}$, after a thermal treatment at $1100{ }^{\circ} \mathrm{C}$ in air, showing no reaction products between both phases other than the initial reactants. The first and second series of Bragg positions correspond to $\mathrm{Sr}_{0.7} \mathrm{R}_{0.3} \mathrm{CoO}_{3-\delta}(\mathrm{R}=\mathrm{Tb}$ and $\mathrm{Er})$ and LSGM, respectively.
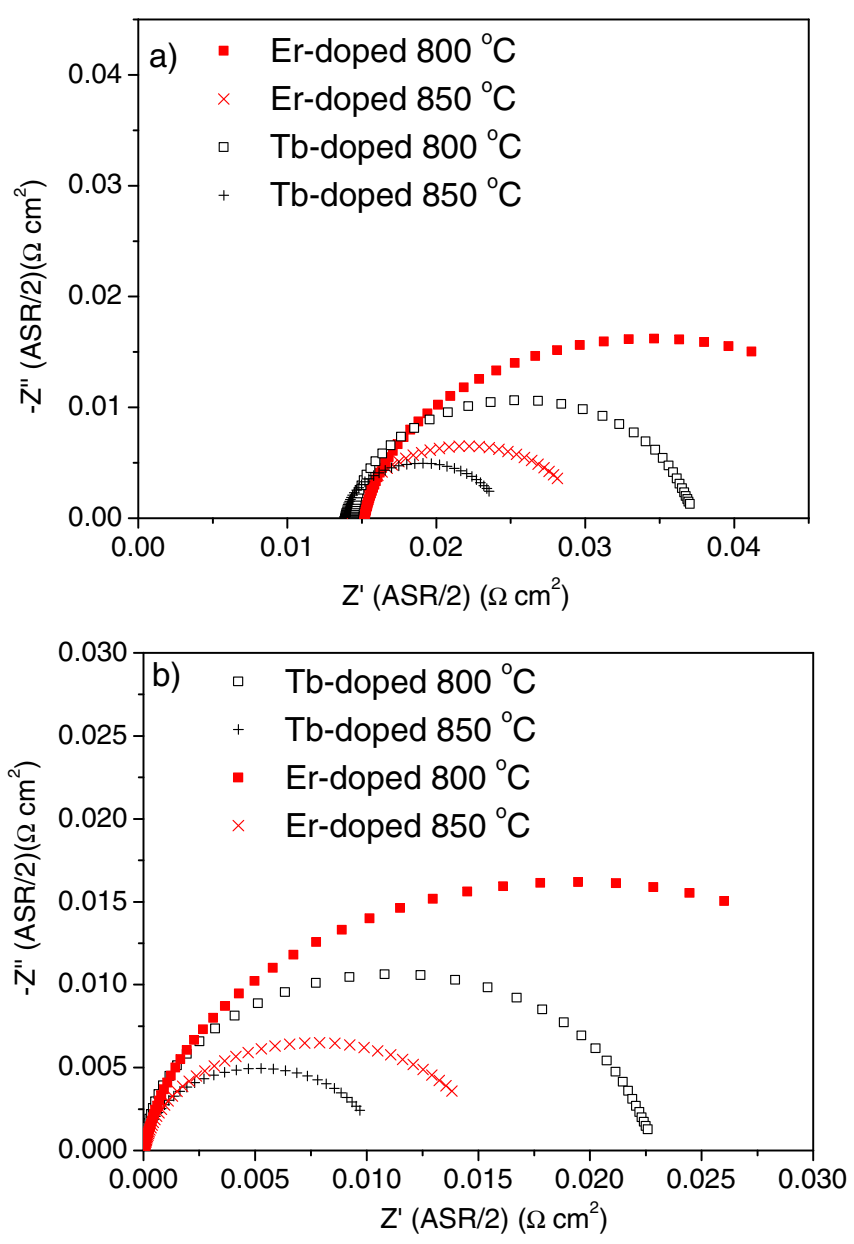

c)

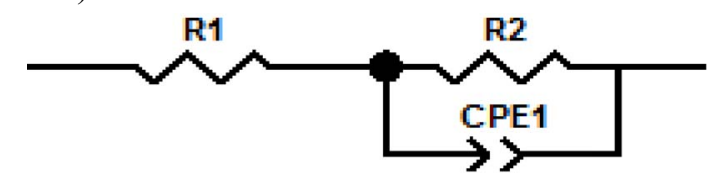

Figure 10. a) Complex impedance spectra for $\mathrm{Sr}_{0.7} \mathrm{~Tb}_{0.3} \mathrm{CoO}_{3-\delta}$ and $\mathrm{Sr}_{0.7} \mathrm{Er}_{0.3} \mathrm{CoO}_{3-\delta}, \mathrm{b}$ ) with the electrolyte resistance (R1) subtracted from the spectra, measured in symmetrical cells, illustrated for $\mathrm{T}=800$ and $850^{\circ} \mathrm{C}$ and c) equivalent circuit.

Chemical compatibility.-Figure 9a illustrates the absence of chemical reactivity between $\mathrm{Sr}_{0.7} \mathrm{~Tb}_{0.3} \mathrm{CoO}_{3-\delta}$ and the LSGM electrolyte. A mixture of $\mathrm{Sr}_{0.7} \mathrm{~Tb}_{0.3} \mathrm{CoO}_{3-\delta}$ combined with LSGM in 50 $\mathrm{wt} \%$ of each one was mixed and calcined in air at $1100^{\circ} \mathrm{C}$ for $24 \mathrm{~h}$ in air atmosphere. Figure 9a corresponds to the XRD Rietveld analysis of the products after the thermal treatment, showing no observable reaction between the electrode material and the electrolyte. That result means that the electrode and the electrolyte are chemically compatible and they can be used together in a SOFC. A similar result was obtained for $\mathrm{Sr}_{0.7} \mathrm{Er}_{0.3} \mathrm{CoO}_{3-\delta}$ as shown in Figure $9 \mathrm{~b} . \mathrm{Er}_{2} \mathrm{O}_{3}$ impurity, also detected by NPD, appears in Figure $9 \mathrm{~b}$.

Electrode performance characterization (ac impedance measurements).- The electrode performance was first evaluated by electrochemical impedance spectroscopy on symmetrical cells $\mathrm{Sr}_{0.7} \mathrm{~Tb}_{0.3} \mathrm{CoO}_{3-\delta} / \mathrm{LSGM} / \mathrm{Sr}_{0.7} \mathrm{~Tb}_{0.3} \mathrm{CoO}_{3-\delta}$ and $\mathrm{Sr}_{0.7} \mathrm{Er}_{0.3} \mathrm{CoO}_{3-\delta} /$ LSGM / $\mathrm{Sr}_{0.7} \mathrm{Er}_{0.3} \mathrm{CoO}_{3-\delta}$ over the temperature range $800-850^{\circ} \mathrm{C}$ in air. The electrolyte contribution is taken into account by the introduction of a series resistance (R1) in the equivalent circuit employed for fitting the experimental data (Figure 10c), whereas the 


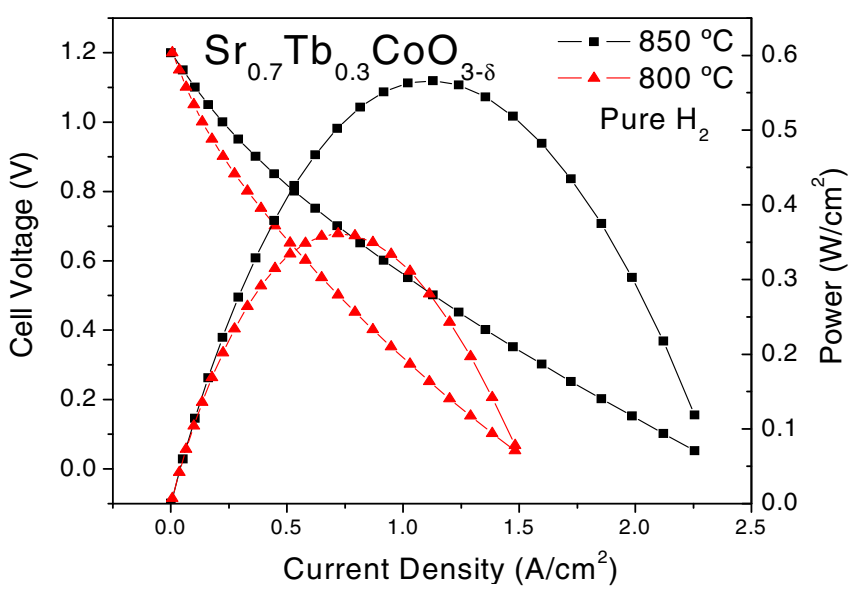

Figure 11. Cell voltage (left axis) and power density (right axis) as a function of the current density for the test cell with the configuration $\mathrm{SMFO} / \mathrm{LDC} / \mathrm{LSGM} / \mathrm{Sr}_{0.7} \mathrm{~Tb}_{0.3} \mathrm{CoO}_{3-\delta}$ in pure $\mathrm{H}_{2}$ measured at $\mathrm{T}=800$ and $850^{\circ} \mathrm{C}$ with $\mathrm{Pt}$ as current collector.

polarization process is simulated by a RP-CPE elements (R2, CPE1). Figure 10a shows the temperature dependence of the interfacial polarization resistances $(R p)$ for $\mathrm{Sr}_{0.7} \mathrm{~Tb}_{0.3} \mathrm{CoO}_{3-\delta}$ and $\mathrm{Sr}_{0.7} \mathrm{Er}_{0.3} \mathrm{CoO}_{3-\delta}$ electrodes measured with symmetrical cells in which the electrolyte resistance (R1) is practically the same in all cases. In Figure 10b the electrolyte resistance (R1) was subtracted from the spectra in order to have an estimation of the electrode polarization as a function of temperature. The results were also multiplied by the electrode area and 0.5 to account for the contribution of both electrodes. As temperature increases the resistance decreases in both samples. Electrode polarization resistances as low as $0.011 \Omega \cdot \mathrm{cm}^{2}$ at $850^{\circ} \mathrm{C}$ for $\mathrm{Sr}_{0.7} \mathrm{~Tb}_{0.3} \mathrm{CoO}_{3-\delta}$ and $0.015 \Omega \cdot \mathrm{cm}^{2}$ for $\mathrm{Sr}_{0.7} \mathrm{Er}_{0.3} \mathrm{CoO}_{3-\delta}$ as the same temperature warrant the good performance of these materials as cathodes in SOFC using LSGM as electrolyte. These values are comparable to those described in previous works for good cathode materials with related compositions..$^{14,16}$

Fuel-cell tests. - The performance of $\mathrm{Sr}_{0.7} \mathrm{R}_{0.3} \mathrm{CoO}_{3-\delta}(\mathrm{R}=\mathrm{Tb}$ and $\mathrm{Er}$ ) as cathodes in SOFCs was evaluated in single-cell tests in an electrolyte-supported configuration using a $300 \mu \mathrm{m}$-thick LSGM electrolyte. Figure 11 illustrates the cell voltage and power density as a function of the current density at 800 and $850^{\circ} \mathrm{C}$ for the single cells fed with pure $\mathrm{H}_{2}$ for the cathode with $\mathrm{R}=\mathrm{Tb}$. The maximum

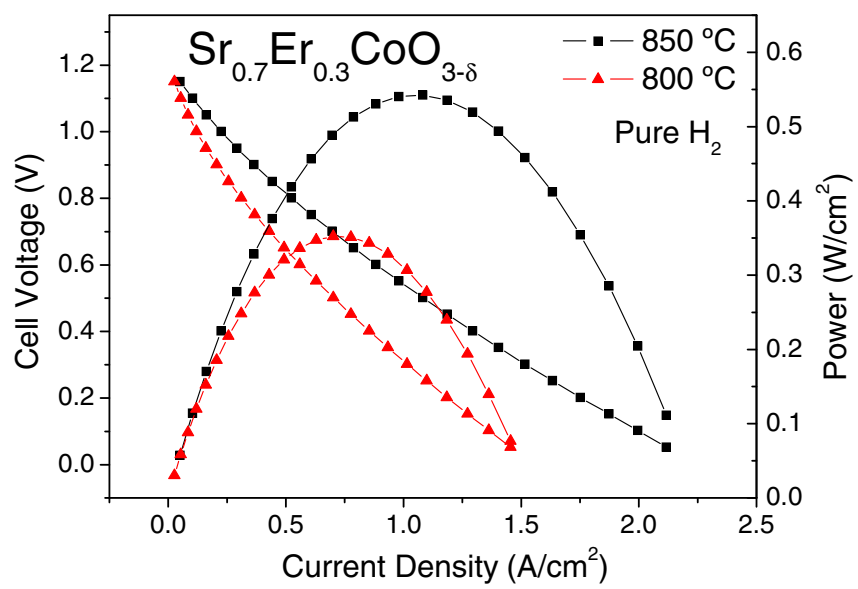

Figure 12. Cell voltage (left axis) and power density (right axis) as a function of the current density for the test cell with the configuration SMFO/LDC/LSGM/Sr ${ }_{0.7} \mathrm{Er}_{0.3} \mathrm{CoO}_{3-\delta}$ in pure $\mathrm{H}_{2}$ measured at $\mathrm{T}=800$ and $850^{\circ} \mathrm{C}$ with $\mathrm{Pt}$ as current collector.

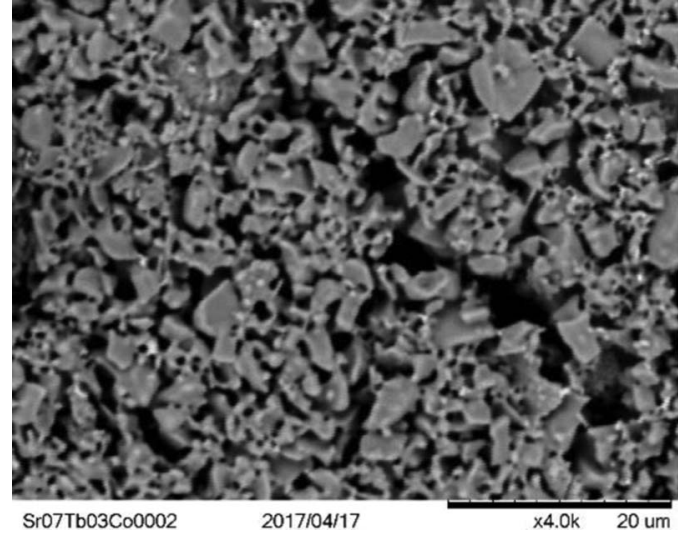

Figure 13. SEM image (magnification 4000x) of the cathodic side of the cell $\left(\mathrm{Sr}_{0.7} \mathrm{~Tb}_{0.3} \mathrm{CoO}_{3-\delta}\right)$ after the cell test. A large interconnected porosity is observed, important for the air diffusion across the cathode material.

power densities generated by this cell were 362 and $570 \mathrm{~mW} / \mathrm{cm}^{2}$, respectively. This remarkable performance is due to a good compromise between determinant factors, the catalytic activity and the presence of a large number of oxygen vacancies that satisfy the requirements of a MIEC electrode. Similar results were obtained for $\mathrm{R}=\mathrm{Er}$ (354 and $542 \mathrm{~mW} / \mathrm{cm}^{2}$, at $800^{\circ} \mathrm{C}$ and $850^{\circ} \mathrm{C}$, respectively; Figure 12). Although both cathodes exhibit a good behavior, a little increase of the output power of the single cells for $\mathrm{R}=\mathrm{Tb}$ with respect to $\mathrm{R}=\mathrm{Er}$ is observed. This increase is certainly related to the higher electrical conductivity and the lower polarization resistances observed for the $\mathrm{Tb}$ perovskite.

Postmortem SEM study.-Fig. 13 shows a SEM image of the cathodic side of $\mathrm{Sr}_{0.7} \mathrm{R}_{0.3} \mathrm{CoO}_{3-\delta}$ deposited on LSGM after the test cell working at a maximum temperature of $850^{\circ} \mathrm{C}$. The figure displays a large interconnected porosity, with different-sized grains showing a good electrical connection.

\section{Conclusions}

In this study we have shown that the novel $\mathrm{Sr}_{0.7} \mathrm{R}_{0.3} \mathrm{CoO}_{3-\delta}(\mathrm{R}=$ $\mathrm{Tb}$ and $\mathrm{Er}$ ) perovskite oxides can be successfully employed as cathode materials in SOFCs with LSGM as the electrolyte. The structural features obtained from in-situ temperature-dependent NPD data in air for $\mathrm{Sr}_{0.7} \mathrm{R}_{0.3} \mathrm{CoO}_{3-\delta}(\mathrm{R}=\mathrm{Tb}$ and $\mathrm{Er})$ and ${ }^{18} \mathrm{O}$ trace diffusion experiments for $\mathrm{Sr}_{0.7} \mathrm{R}_{0.3} \mathrm{CoO}_{3-\delta}(\mathrm{R}=\mathrm{Tb})$ evidence an excellent behavior as MIEC oxides. The crystal structure, refined in the $14 / \mathrm{mmm}$ space group, contains significant amount of oxygen vacancies, mainly concentrated at $\mathrm{O} 4$ positions, along with high displacement parameters suggesting high $\mathrm{O}^{2-}$ ion mobility. $\mathrm{Sr}_{0.7} \mathrm{R}_{0.3} \mathrm{CoO}_{3-\delta}(\mathrm{R}=\mathrm{Tb}$ and $\mathrm{Er})$ materials show high electronic conductivity, between $100-150 \mathrm{Scm}^{-1}$ at $850^{\circ} \mathrm{C}$, and $\mathrm{Sr}_{0.7} \mathrm{R}_{0.3} \mathrm{CoO}_{3-\delta}(\mathrm{R}=\mathrm{Tb})$ exhibits self-diffusion coefficient $\left(D^{*}\right)$ and surface exchange coefficient $(k)$ similar to those obtained for other cobaltites, confirming a good oxide ion diffusivity. The polarization resistances in the electrode-electrolyte interlayer are extremely low in both compounds, reaching ASR values of $0.011 \Omega \cdot \mathrm{cm}^{2}$ at $850^{\circ} \mathrm{C}$ for $\mathrm{Sr}_{0.7} \mathrm{~Tb}_{0.3} \mathrm{CoO}_{3-\delta}$. Maximum power density of $570 \mathrm{~mW} / \mathrm{cm}^{2}$ at $850^{\circ} \mathrm{C}$ with pure $\mathrm{H}_{2}$ as a fuel for $\mathrm{Sr}_{0.7} \mathrm{~Tb}_{0.3} \mathrm{CoO}_{3-\delta}$ obtained in the single test cell confirm the suitability of these materials to catalyze the oxygen reduction under SOFC conditions Even if the thermal expansion coefficients for these materials are slightly higher than the values presented by the other cell components, the compatibility with LSGM was demonstrated in the single cell tests. 


\section{Acknowledgments}

We thank the financial support of the Spanish Ministry of Economy and Competitiveness to the project MAT2013-41099-R.We thank the Institut Laue-Langevin (ILL) for making all facilities available.

\section{References}

B. C. H. Steele, Ceram Int., 19, 269 (1993).

2. M. Dokiya, Solid State Ionics, 152, 383 (2002).

3. C. Sun, R. Hui, and J. Roller, J Solid State Electrochem, 14, 1125 (2010).

4. S. B. Adler, Chem. Rev., 104, 4791 (2004).

5. Z. Lei, Q. Zhu, and L. J. Zhao, J. Power Sources, 161, 1169 (2006).

6. T. Tsai and S. A. Barnett, Solid State Ionics, 93, 207 (1997).

7. S. P. Jiang and W. Wang, J. Electrochem. Soc., 152, 1398 (2005).

8. Z. Q. Deng, W. S. Yang, W. Liu, and C. S. Chen, J. Solid State Chem., 179, 362 (2006).

9. L. W. Tai, M. M. Nasrallah, H. U. Anderson, D. M. Sparlin, and S. R. Sehlin, Solid State Ionics, 76, 259 (1995).

10. A. Aguadero, D. Pérez-Coll, J. A. Alonso, S. J. Skinner, and J. Kilner, Chem. Mater. 24, 2655 (2012).

11. S. F. Wang, Y. F. Hsu, C. T. Yeh, C. C Huang, and H. C. Lu, Solid State Ion, 227, 10 (2012).

12. A. Aguadero, J. A. Alonso, D. Perez-Coll, C. de la Calle, M. T. Fernández-Díaz, and J. B. Goodenough, Chem. Mater, 22, 789 (2010).

13. V. Cascos, R. Martínez-Coronado, and J. A. Alonso, Int. J. Hydrog. Energy, 39, 14349 (2014).

14. Y. Li, Y. N. Kim, J. Cheng, J. A. Alonso, Z. Hu, Y. Chin, T. Takami, M. T. Fernández-Díaz, H. J. Lin, C. T. Chen, L. H. Tjeng, A. Manthiram, and J. B. Goodenough, Chem. Mater, 23, 5037 (2011).
15. T. Liu, Y. Li, and J. B. Goodenough, J. Power Sources, 199, 161 (2012).

16. T. Liu, Fuel Cells, 13, 1056 (2013).

17. H. M. Rietveld, J. Appl. Crystallogr., 2, 65 (1969).

18. J. Rodríguez-Carvajal, Physica B, 192, 55 (1993).

19. R. A. De Souza, J. Zehnpfenning, M. Martin, and J. Maier, Solid State Ionics, 176, 1465 (2005).

20. R. J. Chater, S. Carter, J. Kilner, and B. C. H. Steele, Solid State Ionics, 53-56, 859 (1992).

21. J. Crack, Oxford University Press, The Mathematics of Diffusion, Oxford (1975).

22. R. Martínez-Coronado, J. A. Alonso, A. Aguadero, and M. T. Fernández-Díaz, J Power Sources, 208, 153 (2012).

23. S. Y. Istomin, J. Grins, G. Svensson, O. A. Drozhzhin, V. L. Kozhevnikov, E. V. Antipov, and J. P. Attfield, Chem. Mater, 15, 4012 (2003).

24. I. O. Troyanchuk, D. V. Karpinskii, A. P. Sazonov, V. Sikolenko, V. Efimov, and A. Senyshyn, J Mater Sci, 44, 5900 (2009).

25. N. O. Golosova, D. P. Kozlenko, L. S. Dubrovinsky, O. A. Drozhzhin, S. Y. Istomin, and B. N. Savenko, Phys. Rev. B, 79, 104431 (2009).

26. R. L. Withers, M. James, and D. J. Goossens, J. Solid State Chem., 174, 198 (2003).

27. V. Cascos, R. Martínez-Coronado, J. A. Alonso, and M. T. Fernández-Díaz, ACS Applied materials\&Interfaces, 6, 9194 (2014).

28. R. D. Shannon, Acta. Crystallogr. A, 32,751 (1976).

29. J. W. Stevenson, K. Hasinska, N. L. Canfield, and T. R. Armstrong, J Electrochem Soc, 147, 3213 (2000).

30. A. Aguadero, C. de la Calle, J. A. Alonso, M. J. Escudero, M. T. Fernández-Díaz, and L. Daza, Chem. Mater., 19, 6437 (2007)

31. Y. Shen, F. Wang, X. Ma, and T. He, J Power Sources, 196, 7420 (2011).

32. E. Boehm, J. M. Bassat, M. C. Steil, P. Dordor, F. Mauvy, and F. C. Grenier, Solid State Sci, 5, 973 (2003).

33. D. P. Rupasov, A. V. Berenov, J. A. Kilner, S. Y. Istomin, and E. V. Antipov, Solid State Ionics, 197, 18 (2011).

34. J. A. Kilner and M. Burriel, Annu. Rev. Mater. Res., 44, 365 (2014). 